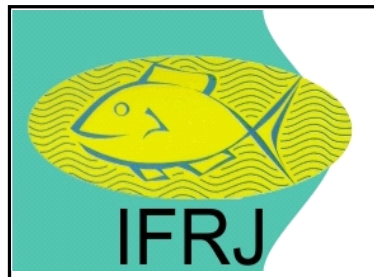

Available online at: http://ejournal-balitbang.kkp.go.id/index.php/ifrj

e-mail:ifrj.puslitbangkan@gmail.com

INDONESIANFISHERIES RESEARCHJOURNAL

Volume 23 Nomor 2 December 2017

e-ISSN: 2502-6569

Accreditation Number: 704/AU3/P2MI-LIPI/10/2015

\title{
POPULATION PARAMETERS AND REPRODUCTIVE BIOLOGY OF INDIAN MACKEREL Rastrelliger kanagurta (Cuvier, 1817) CAUGHT BY LIFT NET IN KWANDANG WATERS, NORTH GORONTALO
}

\author{
Ria Faizah ${ }^{\star 1}$ Lilis Sadiyah $^{1}$ and Moh. Fauzi ${ }^{2}$ \\ ${ }^{1}$ Center for Fisheries Research, Jl. Pasir Putih II Ancol Timur, Jakarta Utara-14430, Indonesian \\ ${ }^{2}$ Research Institute of Marine Fisheries, Jl. Muara Baru Ujung, Komp Pelabuhan Perikanan Nizam Zachman, Penjaringan \\ Received; August 15-2017 Received in revised from February 05-2018; Accepted February 07-2018
}

\begin{abstract}
The waters Kwandang are one of the main fishing grounds for small pelagic fisheries in Sulawesi Sea in where the Indian mackerel (Rastrelliger kanagurta) has been exploited. The objective of the research was to estimate population parameters of indian mackerel that included: growth, mortality, gonad maturity and exploitation rate. Length frequency data were collected from Coastal Fishing Port of Kwandang, from January to November 2012. Estimation of population parameters of Indian mackerel was done using FISAT II software. The results show that growth rate were as follows $(K)=0.80$ year $^{-1}, L_{\infty}=27.3 \mathrm{~cm}$. Total mortality rate $(Z)$ was 2.72 year ${ }^{-1}$, with natural mortality $(M)=1.29$ year $^{-1}$ and consequently, fishing mortality $(F)$ was 1.43 year $^{-1}$ and exploitation rate $(E)=0.53$. This indicates the exploitation of Indian mackerel in Kwandang waters has reached its optimum level. The sex ratio of Indian mackerel was balance. The most common specimens is found at immature stage of I. Based on the results, it is suggested that precautionary approach through responsible management should be applied through several possibilities such as increasing of the mesh size of the gears, restricting additional lift net, restricting fishing for certain seasons, declaring fish sanctuaries in certain areas, especially in spawning grounds to protect the Indian mackerel.
\end{abstract}

Keyword: Indian mackerel; population parameter; biology; Kwandang

\section{INTRODUCTION}

Small pelagic fish resources in Sulawesi Sea are one of important marine fish commodities that have been exploited since decades. Indian mackerel as one of common species of small pelagic fish plays a vital role in feeding the local and national population and contributing significantly to the dietary protein intake. In relation to optimize the national fisheries management, all fisheries activities in Sulawesi Sea are representing to Indonesian Fisheries Management Area (IFMA) 716 (MR' No. 18/PERMEN-KP/2014).

The catches of small pelagic fish are mostly landed in several landing places along the coast of this region such as Tumumpa, Bitung, North Minahasa and Kwandang, North Gorontalo. Kwandang geographically located in Northern part of Gorontalo Province. Marine capture fisheries sector in North coast of Gorontalo province was facilitated by Kwandang Coastal Fishing Port (CFP). Since the area

\footnotetext{
${ }^{1}$ MR: Ministerial Regulation
}

geographically is located in Sulu-Sulawesi marine ecoregion with neighbouring Indonesia's Seas and South China Sea it lies at the center of the world's tropical marine biodiversity. Surrounded by three developing nations, the Philippines, Indonesia and Malaysia (DeVantier et al. 2004), sustaining marine biodiversity become a trans-boundary issue. Species of pelagic fish in this region are potential exploited such as tuna, tuna like species, Indian mackerel (Rastrelliger kanagurta), scad (Selar sp), and other pelagic species. Based on 2015 annual landing data, in Kwandang CFP, the catches were dominated by small pelagic fishes up to $74 \%$ or about 3,996 tons with total production of 5,408,7 tons (Kwandang Coastal Fishing Port, 2015).

Fisheries Statistics of 2005-2015 showed that there were 7 dominant species of small pelagic fishes in North Gorontalo Regency i.e., mackerel scad (Decapterus macarelus), short-fin scad (Decapterus macrosoma), indian mackerel (Rastrelliger kanagurta), white sardine, anchovy (Stolephorus spp), spotted sardine (Amblygaster sirm) and bigeye scad 
(Selar crumenophthalmus). The average production of small pelagic fishes between 2005 - 2011 was $40 \%$ of total fisheries production and increasing gradually by $14 \%$ year ${ }^{-1}$. The fishes were caught by purse seine or mini purse seine/pajeko, gillnet, lift net and hook and line. Suwarso et al (2013) stated that exploitation of small pelagic in Sulawesi Sea waters increased year by year. This situation will worsen the sustainability of small pelagic fish in this water.

The Indian mackerel (Rastrelliger kanagurta) is species of mackerel in the family Scombridae of order Perciformes. It is a pelagic schooling fish widely distributed in the Indian Ocean and Indo-West Pacific region. Adult fishes occur in coastal bays, harbors and deep lagoons. Indian mackerel Information on parameter population and biology for small pelagic fish especially Indian mackerel in Kwandang is less available compared to Java Sea. This study was undertaken to estimate that population parameters of Indian mackerel, included: growth, mortality, gonad maturity and exploitation rate. That are required to support a management strategy for the rational exploitation of this species in the Kwandang waters. The output is expected to strengthen the baseline information for fisheries management issues in IFMA

716 particularly the aspects of population dynamics that may be conceptually important to develop bioexploitation indicators of Indian mackerel. Density dependent population regulation among immature stages has important implications for healthy fish populations, primarily because it can lead to indicate their sustainability index.

\section{MATERIALS AND METHODS Period and sampling site}

Monthly sampling was carried out between January-November 2012 from small scale commercial vessels. Sampling site is located in Kwandang Coastal Fishing Port, which geographically located in 0॰51'12.44" N \& 122 $53^{\prime} 50.87^{\prime \prime}$ E. Several measurements (to the nearest $\mathrm{cm}$ fork length) were carried out on regular monthly based observation (length data were available from February to October 2012). A total of 4.022 individuals were measured in field during for 11 months observation. Sampling was randomly measured from the landing by well-trained local enumerators. Reproduction data were obtained through macroscopic observation using maturity stages criteria developed by lsa et al. (2002) ( Table 1).

Table 1. Maturity Criteria of Indian Mackerel (Isa et al., 2002)

\begin{tabular}{|c|c|c|}
\hline Stage of maturity & State & Description \\
\hline 1 & Immature & $\begin{array}{l}\text { Ovary and testis are small, transparent, occupying about } 1 / 2 \text { of body } \\
\text { cavity, ova not visible to naked eye. GSI: } 0,11-2,69\end{array}$ \\
\hline II & Maturing & $\begin{array}{l}\text { Ovary and testis are occupying up to } 1 / 2 \text { body cavity. Testis is whitish, } \\
\text { simetric, ovary is rendess clear, ova not visible to naked eye. GSI: } 0,28 \\
4,75\end{array}$ \\
\hline III & Ripening & $\begin{array}{l}\text { Ovary and testis are occupying about } 1 / 2 \text { to } 2 / 3 \text { of body cavity. Testis is } \\
\text { white, ovary is pinkish yellowish, granular ova visible to naked eye. GSI } \\
0,59-7,19\end{array}$ \\
\hline IV & Mature/Ripe & $\begin{array}{l}\text { Ovary and testis are occupying about } 2 / 3 \text { to full length body cavity. } \\
\text { Testis is white and soft, ovary is orange-pink, large ova oozes, ripe and } \\
\text { translucent. GSI: } 2,59-11,24\end{array}$ \\
\hline V & Spent & $\begin{array}{l}\text { Ovary and testis are occupying up to } 1 / 2 \text { body cavity. Shrunken, reddish, } \\
\text { wall loose. Testis is soft and reddish. Ovary is consisted of ripe ova, } \\
\text { transparant. GSI: } 0,53-7,73\end{array}$ \\
\hline
\end{tabular}




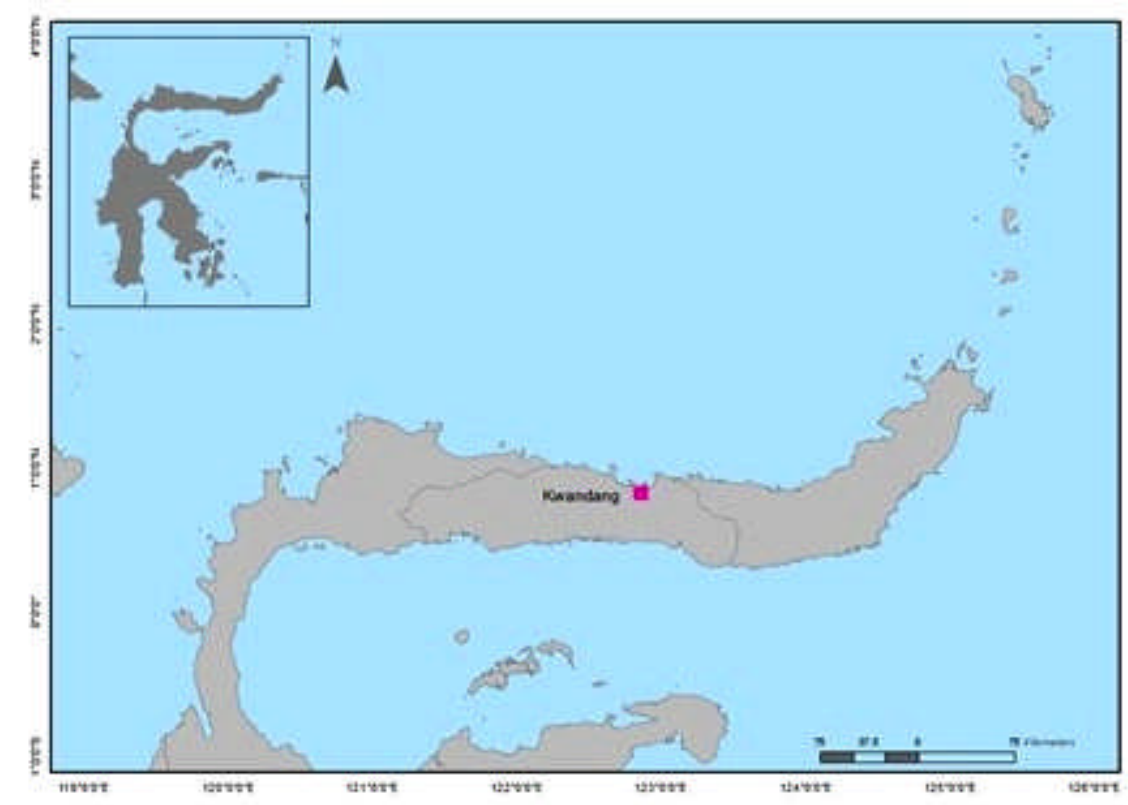

Figure 1. Map showing the sampling site in Kwandang Waters, North Gorontalo Province.

\section{Parameter Examined}

Total number of samples were 4.022 individuals. Parameters examined were body fork length in centimeters $(\mathrm{cm})$, body and gonad weight in grams (g). Length frequency measurements were carried out using measuring board. Body and gonad weight were carried out by digital scales

\section{Data Analysis Growth Parameters}

Growth parameters were estimated based on monthly length-frequency data. The length frequency was analyzed using the FiSAT Software (Gayanilo et al., 2005). Asymptotic length $\left(L_{\infty}\right)$ and growth coefficient $(K)$ of the von Bertalanffy growth function (VBGF) were calculated by using ELEFAN-1 (Pauly \& David, 1981). The growth model using equation:

$L_{t}=L_{\infty}\left(1-e^{-k(t-t o)}\right)$

where;

$\mathrm{L}_{\mathrm{t}}=$ fish length $(\mathrm{cm})$ when age $\mathrm{t}$ (year),

$\mathrm{L}_{\infty}=$ asymptotic length $(\mathrm{cm})$,

$\mathrm{K}=$ the growth coefficient,

To $=$ theoretical age at fish length $=0$ (year),

$\mathrm{t}=$ age (year)

\section{Total Mortality (Z)}

Total mortality $(Z)$ was estimated using the length converted catch curve (Pauly, 1984) and the natural mortality rate $(\mathrm{M})$ was estimated by using empirical relationship suggested by Pauly (1980):
Ln $M=-0.0066-0.279 L n L_{\infty}+0.6453$ Ln $K+$ $0.4634 \operatorname{Ln~T}$

where;

$\mathrm{M}=$ the natural mortality,

$\mathrm{L}_{\infty}=$ the asymptotic length,

$\mathrm{K}=$ the growth coefficient of the VBGF and

$\mathrm{T}=$ the mean annual habitat water temperature.

The value of total mortality $(Z)$ represented by the value of slope (b) between $\mathrm{Ln} \mathrm{N/t}$ and relative age (t) when the slope decrease/negative. Once $Z$ and $M$ was obtained, then fishing mortality $(F)$ was estimated using the relationship:

$\mathbf{F}=\mathbf{Z}-\mathbf{M}$

where;

$Z$ = the total mortality,

$\mathrm{F}=$ the fishing mortality and

$M=$ the natural mortality.

The exploitation level (E) was obtained by the relationship of King (1995):

$E=F / Z=F /(F+M)$

\section{Maturity Stage}

Maturity stages were detected through a morphological examination of the gonads by visual. Gonadosomatic index (GSI) was calculated using the Equation: 
$\mathrm{GSI}=(\mathrm{Wg} / \mathrm{W}) \times 100 \%$

where;

GSI = gonado somatic index;

$\mathrm{Wg}=$ gonado weight (gram)

$\mathrm{W}$ = fish weight (gram) (Effendie, 2002).

GSI will increase and reach maximum limit when fish at spawning stage. Female has GSI higher than male. Sometimes GSI was related to Gonado Maturity Stage so there would any relationship between inside and outside gonad development or morphology values were quantitatived (Effendie, 2002).

\section{Statistical analysis}

The sex ratio is the basic information needed for the assessment of the potential of reproduction and stock status estimation. The difference between sex ratio was analyzed through the Chi-square $\left(\mathrm{X}^{2}\right)$ test.

\section{RESULTS AND DISCUSSION \\ Results \\ The Fisheries}

Kwandang district located in North Gorontalo Regency, has relatively long coast line. The number of fishery households in this area is about 2.666 units with more than 2.000 boats, of which 1.678 of these

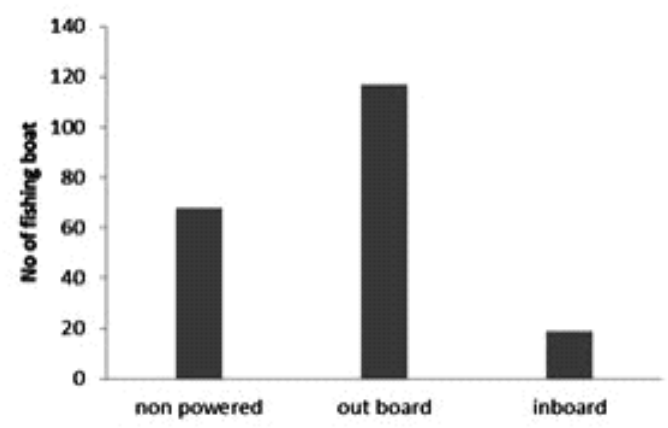

are boats with outboard motors. The production of marine fishery in 2015 reached at about 23.5 thousand tons, of which tuna and skipjack are the main commodities, each commodity reaches 4.000 tons per year. Small pelagic fish is also the major species targeted by small scale fisheries (BPS, 2016).

The fleet structure consisted of 33\% non-powered boat, $57 \%$ outboard and $9 \%$ inboard, this indicated that most of boats are operated in coastal waters. This proportion indicated that the existing small pelagic fisheries involving fishing household using small amount of capital and energy, small fishing vessels, short fishing trips, close to shore and mostly for local consumption. Two major fishing gears targeting small pelagic fish are pure seine and boat operated lift net (Figure 2) (BPS, 2016).

\section{Catch Composition}

Indian mackerel in Kwandang was caught by three types of fishing gears. They were mini purse seine (locally name as pajeko), lift net, and hook and line. Based on monthly landing data from January to November 2012, Indian mackerel was mostly caught by lift net than other fishing gears. The monthly data show that the highest landing occurred in May then gradually decreased to the end of the year, whereas the lowest occurred in February. (Figure 3).

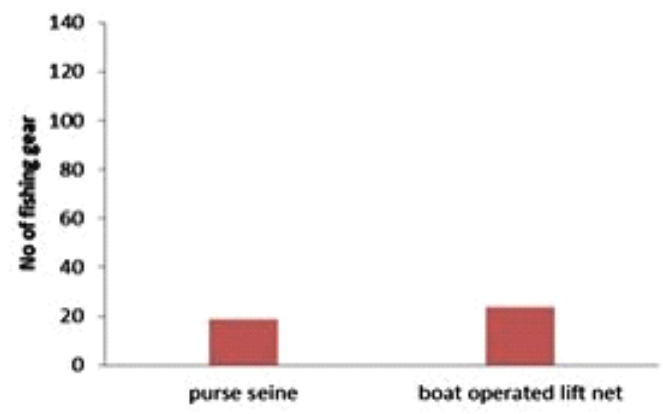

Figure 2. Fleet structure and fishing gears in Kwandang in 2015.

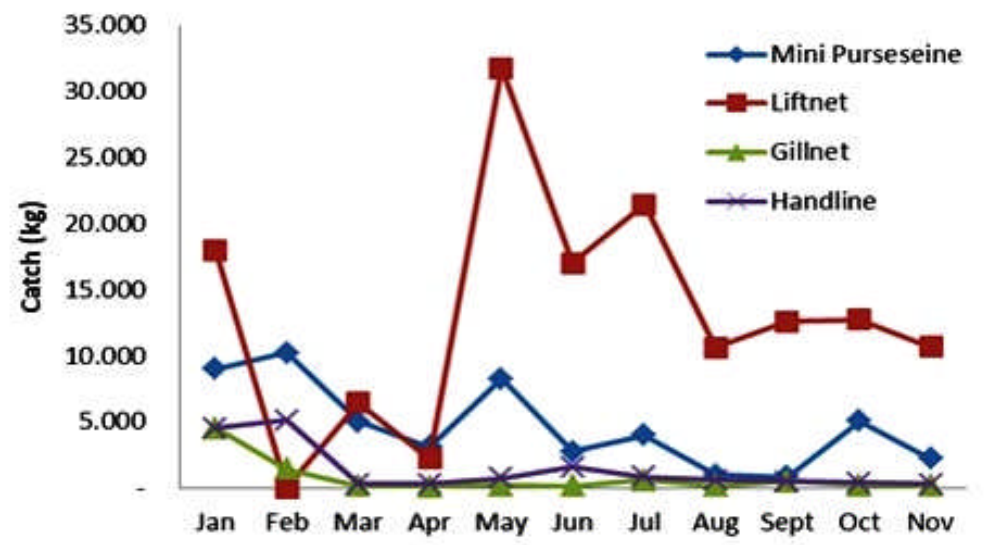

Figure 3. Catch of Indian mackerel based on fishing gear in CFP Kwandang. 
Catch composition of 6 small pelagic species in Kwandang and its adjacent waters consisted of Scads $31 \%$, fringescale sardine $38 \%$, Anchovies $13 \%$, Indian
Mackerel $8 \%$, spotted sardine and travellies 5\% (Figure 4).

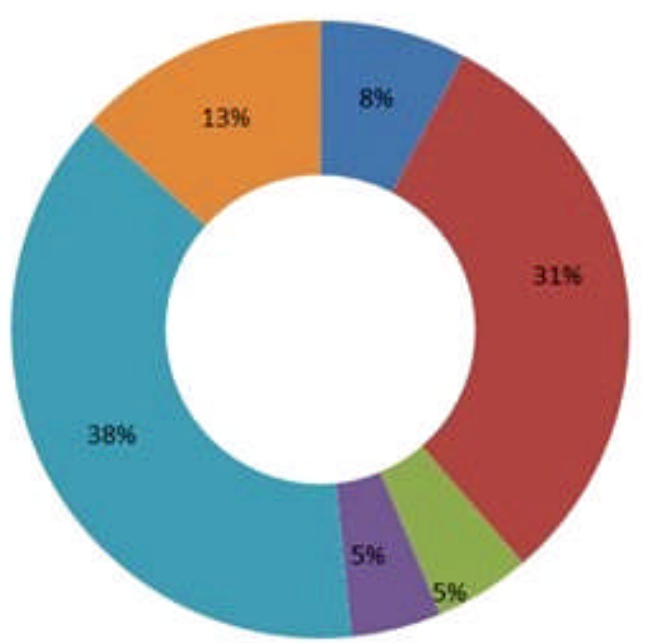

Indian Mackerel

Escads

in Spotted Sardine

n Trevallies

\# Fringescale sardine

anchovies

Figure 4. Catch composition of small pelagic species in Kwandang and its adjacent waters in 2015.

\section{Population Parameters}

Growth Parameters

Growth parameters were carried out by monitoring size distribution of population represented by regular sampling. Number of specimens were fluctuated mainly due to unfavorable weather conditions. Based on sampling activities, the overall of 4.022 individual size of Indian mackerel ranged between $7.25 \mathrm{~cm}$ $25.75 \mathrm{~cm} \mathrm{FL}$ and most of the specimens occurred between $13.75-18.75 \mathrm{~cm}$ FL (Figure 5). The size distribution was aggregated by month in order to obtain a regular time period and a large sample of the population. The result of analyze of FISAT II shows that growth coefficient $(\mathrm{K})$ was 0.80 per year with asymptotic length $\left(L_{\infty}\right)=27.3 \mathrm{~cm}$ FL.

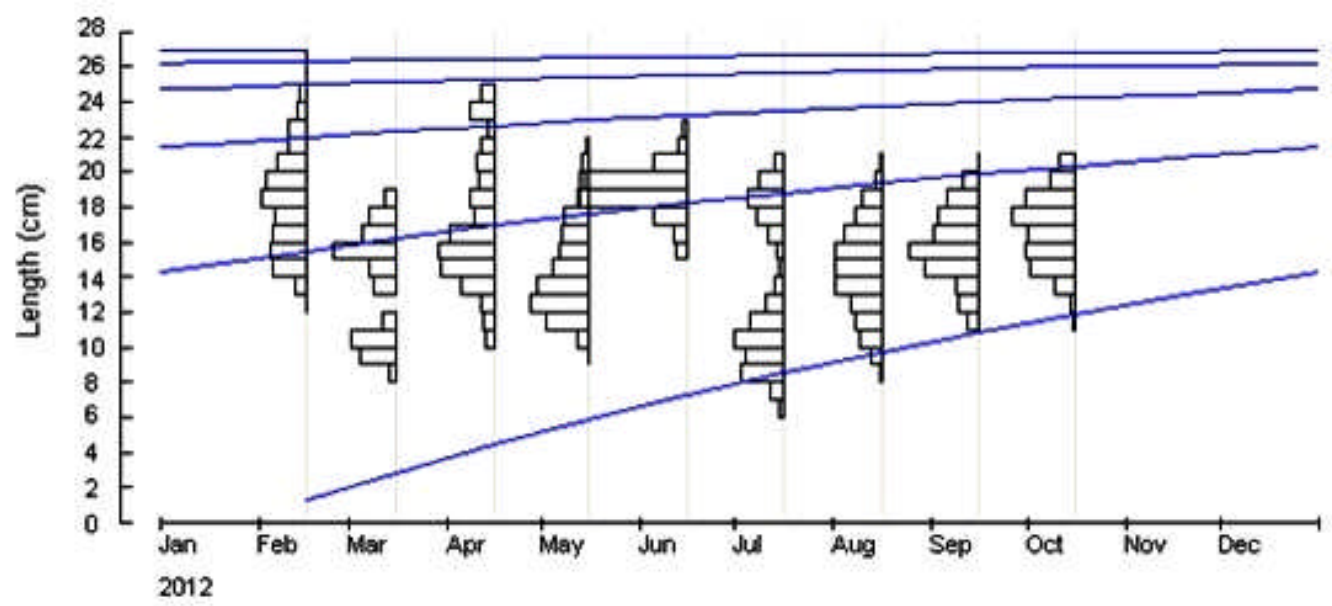

Figure 5. Growth Curve of Indian mackerel in Kwandang Waters in 2012.

Estimation Mortality and Exploitation Rates

Total mortality coefficient (Z) was estimated as 2.72 per year using length converted catch method. Natural mortality $(\mathrm{M})$ was estimated at 1.29 per year. Based on total mortality $(Z)$, fishing mortality $(F)$ was found to be 1.43 per year. The exploitation rate $(E)$ was calculated at 0.53 (Table 2). The fishery in the coastal waters of Kwandang, seemed to be similar with the optimum level of exploitation $(E=0.50)$.

\section{Sex Ratio}

From the total of 307 measured specimens of Indian mackerel, sex ratio between males and females were 1:1.01. Overall, the sex ratio was not significantly different based on chi square test $=13.91$ with $p<0.01$. 
Table 2. Population parameter of indian mackerel landed in PP Kwandang 2012

\begin{tabular}{lcccccc}
\hline \multicolumn{1}{c}{ Species } & \multicolumn{2}{c}{$\begin{array}{c}\text { Parameter of } \\
\text { growth }\end{array}$} & \multicolumn{3}{c}{ Parameter or mortality } & \multicolumn{2}{c}{ Exploitation rate } \\
& $\mathbf{L}_{\infty}$ & $\mathbf{K}$ & $\mathbf{Z}$ & $\mathbf{M}$ & $\mathbf{F}$ & $\mathbf{E}$ \\
\hline $\begin{array}{l}\text { Indian mackerel Rastrelliger } \\
\text { kanagurta }\end{array}$ & 27.3 & 0.80 & 2.72 & 1.29 & 1.43 & 0.53 \\
\hline
\end{tabular}

Tabel 3. Monthly sex ratio of Indian mackerel

\begin{tabular}{lccccc}
\hline \multirow{2}{*}{ Time } & \multirow{2}{*}{ Number of sample } & \multicolumn{2}{c}{ Number (individuals) } & \multicolumn{2}{c}{ Ratio } \\
& & Female & Male & Female & Male \\
\hline Jan & 62 & 35 & 27 & 1.30 & 1.0 \\
Feb & 90 & 43 & 47 & 1.0 & 1.09 \\
March & 56 & 26 & 30 & 1.0 & 1.15 \\
June & 54 & 36 & 18 & 2.00 & 1.0 \\
Nov & 45 & 14 & 31 & 1.0 & 2.21 \\
Total & $\mathbf{3 0 7}$ & $\mathbf{1 5 4}$ & $\mathbf{1 5 3}$ & $\mathbf{1 . 0 1}$ & $\mathbf{1 . 0}$ \\
\hline
\end{tabular}

The Maturity Stage

The reproduction cycles deduced from the material observed indicated that females with maturity stage I and II were predominantly occured every month, while specimens with stage IV only found in November. However, the adult specimens (spent) were found in monthly observations. Based on this limited data, it could be predicted that all the spawning stocks might migrate to the area beyond the local fishing ground of this fisheries, and then revisit the area after spawning seasons (Figure 6).
Monthly changes of gonadosomatic index (GSI) of Indian mackerel are presented in Figure 7. The lowest GSI of Indian mackerel was observed in March and June. GSI of Indian mackerel in November was higher than March and January.

Precentage of immature and mature female is presented in Figure 8. The immature was dominantly occured in each sampling. The irregular monthly proportion on maturity stages shows that the recruitment or juveniles (stage I) occured in the fishery at each month.

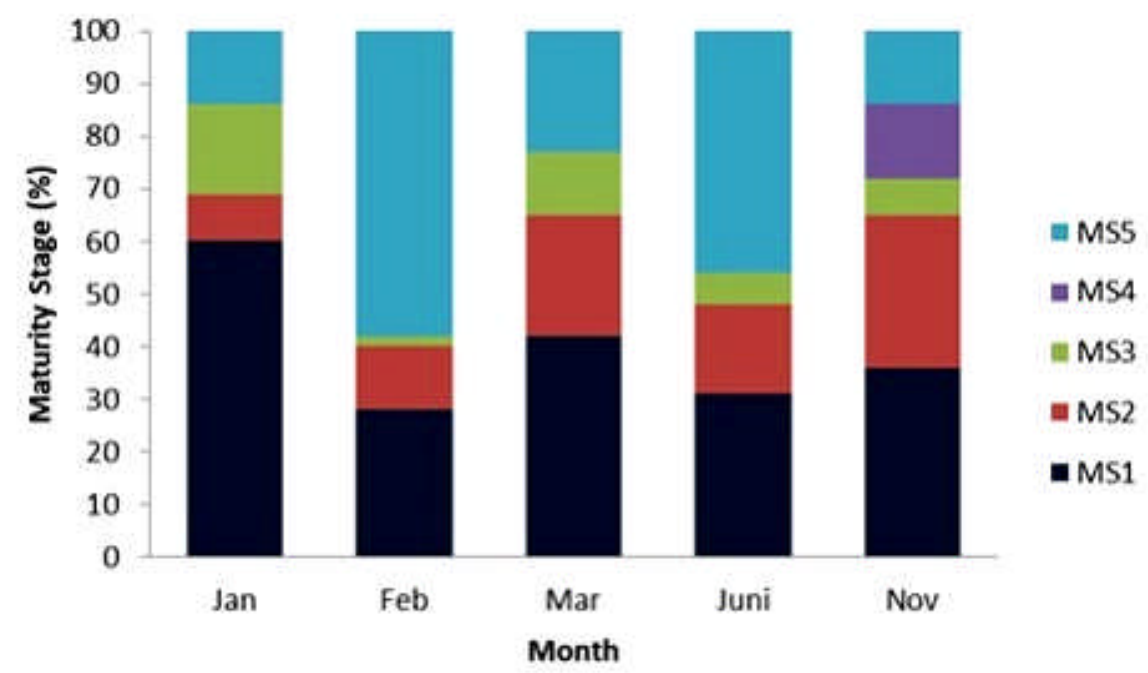

Figure 6. Monthly composition of Maturity Stage of Indian mackerel in Kwandang waters in 2012. 


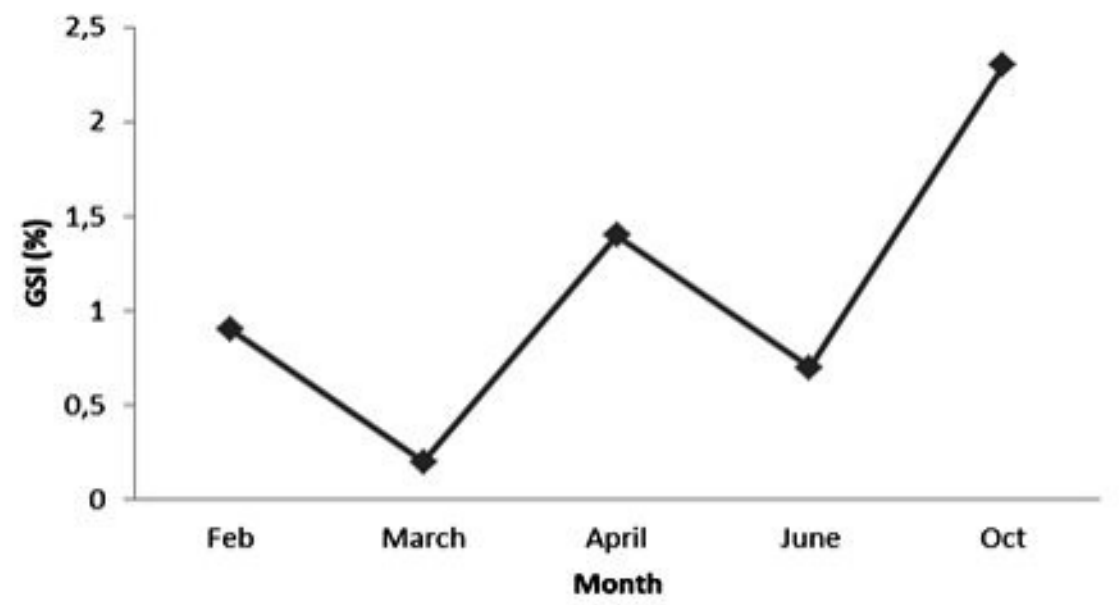

Figure 7. Gonado Index of Indian mackerel in Kwandang waters, 2012.

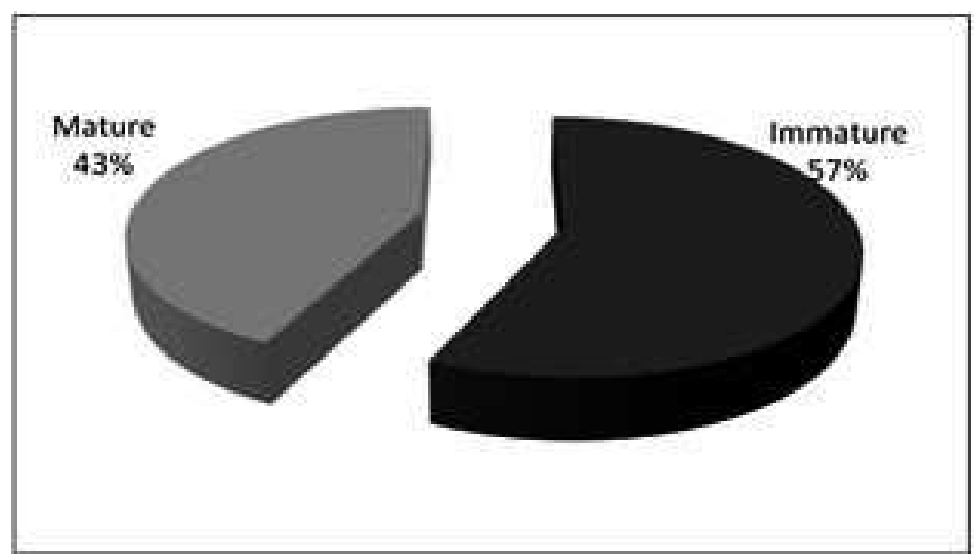

Figure 8. Proportion of female mature and immature of Indian mackarel from Kwandang waters in 2012.

\section{Discussion}

The range of fish length from this study was similar to other study in other location. Arrafi et al. (2016) and Oktaviani et al. (2014) observed that R. kanagurta from Western waters of Aceh and from Mayalibit, Papua respectively with the size ranging between $7-$ $26 \mathrm{~cm}$ FL and 6.3-26 cm FL. Sparre \& Venema (1999) stated thats growth coefficient is the acceleration of growth to achieve the asymptotic length $\left(L_{\infty}\right)$ of the growth pattern of fish.

According to Froese et al. (2000) in Bakhtiar (2013), $\mathrm{K}$ values more than 0.3 per year was categorized high in growth rate. Growth coeffisient (K) of Indian mackerel in this waters was 0.76 per year. Arrafi et al. (2016) stated that K of Indian mackerel from western waters of Aceh was 0.56 per year. Meanwhile, in Sohar coast of Oman, K of Indian mackerel was 0,86 per year (Jayabalan et al., 2014) and in Marudu Bay (Malaysia) was 27.831 .5 (Amin, 2014). Prihatiningsih et al. (2013) stated that the different of growth parameter from the different species was influenced by length structure of fish was often caught, fishing gear and fishing ground.
The natural mortality $(\mathrm{M})$ of Indian mackerel as 1.29 per year and the fishing mortality $(F)$ as 1.43 per year, both mortality rates were relatively equal, then it was estimated fish stock was exploited at optimum level. Gulland (1971) in Sparre \& Venema (1999) stated that stock was expolited optimal if the fishing mortality $(F)$ equal with the natural mortality (M) or exploitation level (E) is 0.5. Atmaja \& Nugroho. (2004) added that mortality was caused by fishing equivalent with effort and catchability; it means that the increase of mortality caused by fishing will be followed by increasing effort. The exploitation level (E) in this study is 0.53 , it means that fish stock is intensive exploited relatively. This value is lower than in Malacca strait which $E=0.74$ (Hariati \& Fauzi, 2010). This suggests that Indian mackerel fishery in Kwandang waters still could be developed with precautionary approach.

Sex ratio of Indian mackerel in Kwandang waters was not significantly different at $5 \%$ level between female and male. This indicates that the opportunity to reproduce still high and ideal conditions to maintain the species (Effendie, 1997). The balance is caused by both of male and female actives then the catch 
opportunity of them are the same. The balancing of male and female fish indicates that the male will fertilize female fish (Senen et al, 2011). This result is different with the previous finding by Hariati et al.(2005) in Malacca straits which showed that male was higher $(54 \%)$ than females (46\%). Accordingly, sex ratio was influenced by the stock status or the exploitation levels (Oktaviani et al., 2014)

Reproduction is one of the important information to understand the magnitude of species on its spawning period. This prediction is one of critical information for conservation of fish stocks. The Indian mackerel females begin to mature (maturity stage III) and being mature (maturity stage IV) was found only in certain months in relatively low number relatively. Female with maturity $\mathrm{V}$ (completed spawning) was found in each month. The spawning season was determined by the occurrence of individuals in maturing, mature, and spent stages. The higher of GSI values are regarded as indicative of spawning season. The present study indicated that spawning season of Indian mackerel in Kwandang waters was in October - November. This result was similar with the study from western waters of Aceh that the higher of GSI values occurred in January-March and AugustOctober (Arrafi et al., 2016). While Rahman \& Hafzath (2012) stated that the peak spawning season of Indian mackerel in the Kuantan coastal waters might fall within the period between the end of January and May.

\section{CONCLUSION}

Exploitation of Indian mackerel in Kwandang waters has reached its optimum level, this is due to fishing mortality and natural mortality are relatively the same. Size of Indian mackerel in Kwandang ranged between $7.25 \mathrm{~cm}-25.75 \mathrm{~cm}$ FL which mostly caught between 13.75-18.75 cm FL. Sex ratio of Indian mackerel was balanced. The fishes were caught mostly immature (stage 1). The spawning season of Indian mackerel is predicted to occur in November. Based on those indicators, it is necessary to reduce the immature size through input control as part of the responsible management such as gradually increase the mesh size of the gears, or restricting additional lift net, or by restricting fishing for certain seasons or declaring fish sanctuaries in certain areas, especially in spawning grounds to protect Indian mackerel

\section{AKNOWLEDGEMENT}

This paper is contributing to Initiation of Implementation EAFM in WPP RI 2012, funded by inhouse research of Research Center for Fisheries Management and Conservation, Jakarta.

\section{REFERENCES}

Amin S.M. N., Mohd Azim, M.K., Fatinah, S.N.J., Arshad, A., Rahman, M.A., \& Jalal K.C.A. (2014). Population parameters of rastrelliger kanagurta (Cuvier, 1816) in the Marudu Bay, Sabah, Malaysia Iranian Journal of Fisheries Sciences, 13(2), 262275.

Arrafi, M., Ambak, A, M., Rumeaida, P. M., \& Muchlisin, Z. (2016). Biology of Indian Mackerel, Rastrelliger kanagurta (Cuvier, 1817) in the Western Waters of Aceh. Iranian Journal of Fisheries Sciences, 15(3), 957- 972.

Atmaja, S. B, \& Nugroho, D. (2004). Characteristics of population parameters of siro fish (Amblygaster sirm) and applied models of Beverton and Holt in the Natuna Sea and surrounding areas. J.Lit.Perik.Ind. 10(4),21-27

Bakhtiar, N.M., Solichin, A., \& Saputra, S.W. (2013). Growth and mortality rate of Spiny lobster (Panulirus homarus) in Cilacap waters of Central Java Diponegoro. Journal of Maquares Management of Aquatic Resources. 2(4), 1-10.

BPS (2016). Kabupaten Gorontalo Utara dalam angka (p. 234). BPS Kabupaten Gorontalo Utara.

Effendie, I. M. (1997). Fisheries biology (p 163). Yayasan Dewi Sri.

Effendie, I. M. (2002). Fisheries biology (p 163 : 59.). Yayasan Dewi Sri.

Gayanilo, Jr., F.C., Sparre, P., \& Pauly, D. (2005). The FAO-ICLARM Stock Assessment Tools II (FiSAT II). Revised version. User's guide. FAO Computerized Information Series (Fisheries). No. 8, Revised version. Rome, FAO. p.168.

Gulland, J.A. (1971). The Fish Resources of the Oceans (p. 209). Fishings News (Books) Ltd. Surrey, England.

Hariati, T, \& M. Fauzi. (2010). Status of development resources of Indian mackerel (Rastrelliger spp.) and the other related species (p. 22). in: On Site Training of Development of capacity for integrity of fisheries and habitat management and Fishing capacity management workshop. Medan, 19-20 Juli 2010. 
Hariati, T. (2005). The development of small petagic resoucce by purse seine fishery of Sibolga in the waters of western Sumatera in year 2003. Indonesia of Journal Fisheries Research. Vol.11 (2), 57-67

Isa, M.M., Runpet, R., Kadir, S.A.S.A., Ishikawa, S., \& Siriraksophon, S. (2002). Standard operating procedur for pilot data and analysis (p. 30). Southeast Asiang Fisheries Development Centre Marine Fishery Resources Development and Management Department.

Jayabalan, N., Zaki, S., Al-Kiyumi, F., Al-Kharusi, L., \& Al Habsi, S. (2014). Age, growth and stock assessment of the Indian mackerel Rastrelliger kanagurta (Cuvier, 1817) along the Sohar coast of Oman Indian. J. Fish, 61(1),1-6.

King, M. (1995). Fisheries biology, assessment and management (p. 341). Fishing News Books, Blackwell Science, Osney Mead, Oxford OX2 OEL, England.

Oktaviani, D., Supriatna, J., Erdmann M. \& Abinawanto, A. (2014). Maturity Stages of Indian Mackerel Rastrelliger kanagurta (Cuvier, 1817) In Mayalibit Bay, Raja Ampat, West Papua. International Journal of Aquatic Science. 5(1), 6776.

Pauly, D. (1980). On the interrelationships between natural mortality, growth parameters and mean environmental temperature in 175 fish stocks. $J$. Cons. Int. Explor. Mer. 39 (3), 179-192.
Pauly, D. \& David, N., (1981). ELEFAN-I BASIC program for the objective extraction of growth parameters from length-frequency data. Meeresforschung, 28(4), 205-211.

Pauly, D. (1984). Some simple methods for the assessment of tropical fish stocks. FAO Fish. Tech.Pap. (234):52p

Prihatiningsih, Sadhomotomo, B., \& Taufik, M. (2013). (In Indonesian) Population dynamic of Purple Spotted Bigeye (Priacanthus Tayenus) in Tangerang Waters - Banten. BAWAL. 5 (2), 8187

Senen, B., Sulistiono, \& Muchsin, I. (2011). Biology Aspects of Layang Deles (Decapterus macrosoma) in Banda Neira waters, Maluku. Proceeding of National Seminar. Small Islands Development 2011. p. 52-60.

Sparre, P. \& S. C. Venema. (1999). Introduction to tropical fish stock assessment. Part I. Manual. FAO Fish. Tech. Pap. No. 306/2, Rev. 2. Rome, FAO. p. 407.

Kwandang Coastal Fishing Port. (2015). Statistic of Kwandang Coastal Fishing Port. Directorat General of Capture Fisheries. Ministry of Marine and Fisheries.

Suwarso, Kuswoyo, A. \& Fauzi, M. (2013). Exploitation of small pelagic fisheries in Sulawesi Sea. Bunga Rampai Status of xploitation Fisheries Resouces in Java Sea and Sulawesi Sea. Research Institute of Marine Fisheries. 